\title{
ANALISIS PERILAKU IBU DALAM PEMBERIAN MP-ASI SECARA DINI MENURUT FAKTOR PENYEBABNYA PADA BAYI DIPUSKESMAS MARGADANA KOTA TEGAL TAHUN 2015
}

\author{
Usmiyati $^{1}$, Iroma Maulida ${ }^{2}$ \\ Email : iroma.maulida@yahoo.co.id \\ ${ }^{12}$ DIII Kebidanan Politeknik Harapan Bersama \\ Jln. Mataram No. 09 Kota Tegal 52142 \\ Telp/Fax (0283)352000
}

\begin{abstract}
Abstrak
Makanan Pendamping Air Susu Ibu ( MP-ASI ) adalah makanan atau minuman yang mengandung zat gizi dan diberikan kepada bayi atau anak usia 6-24 bulan guna memenuhi kebutuhan gizi selain dari ASI. ${ }^{1}$ Pertumbuhan bayi yang optimal dapat dicapai salah satunya dengan pemberian Makanan Pendamping ASI (MP-ASI) sejak bayi berusia 6 bulan. Di Kota Tegal khususnya Puskesmas Margadana dari laporan bulanan diketahui bahwa pada tahun 2013 terdapat 50 dari 134 bayi yang telah mendapat ASI esklusif sampai 6 bulan. Jadi terdapat sekitar 62,7 \% bayi yang mendapatkan MP-ASI terlalu dini/kurang dari 6 bulan. Oleh karena itu peneliti ingin mengetahui faktor-faktor apakah yang mempengaruhi perilaku pemberian makanan MP-ASI pada bayi di Puskesmas Margadana pada tahun 2015. Penelitian ini menggunakan disain cross sectional pada bayi usia $0-6$ sebanyak 57 bayi di Puskesmas Margadana sebagai sampel. Hasil penelitian menunjukkan bahwa dari 57 bayi sebagai sampel maka terdapat $86 \%$ (49 bayi) yang telah mendapatkan MP-ASI secara dini/kurang dari 6 bulan. Setelah dilakukan uji bivariat dengan taraf kesalahan $5 \%$ dan uji chi square maka dapat diketahui tidak ada hubungan antara masing-masing faktor penyebab tersebut dengan perilaku pemberian MP-ASI secara dini $($ p-value $)<0,05$. Hal ini kemungkinan disebabkan karena tidak cukup bukti untuk dilakukan uji hubungan atas hipotesis tersebut karena jumlah sampel yang terlalu kecil, khususnya adalah jumlah ibu yang berperilaku baik / memberikan MP-ASI $\geq 6$ bulan . Perlu diteliti kembali faktor-faktor yang mempengaruhi perilaku pemberian MP-ASI secara dini dengan mempertimbangkan jumlah sampel yang besar, menggunakan disain yang lebih baik ( kasus control) dan menambah variabel yang diteliti se perti persepsiibu tentang ketidakcukupan ASI yang dimilikinya.
\end{abstract}

Kata Kunci :MP-ASI, Analisis Perilaku Factor Penyebab.

\section{Pendahuluan}

ASI menjamin status gizi bayi menjadi baik karena di dalamnya mengandung kekebalan dan zat gizi yang lengkap bagi bayi sesuai dengan kebutuhannya. Akan tetapi setelah bayi berusia lebih dari 6 bulan maka bayi membutuhkan tambahan asupan makanan yang bisa didapatkan dalam MPASI dengan tetap memberikan ASI sampai usia 24 bulan. Sementara itu, berdasarkan laporan dinas kesehatan propinsi, cakupan pemberian ASI eksklusif pada bayi usia 0-6 bulan sebesar $54,3 \%$ pada tahun $2013 .{ }^{2}$

WHO/UNICEF, merekomendasikan empat hal penting yang harus diperhatikan untuk mencapai tumbuh kembang optimal pada bayi dalam global strategy for infant and young child feeding, yaitu: memberikan Air susu ibu kepada bayi segera dalam 30 menit setelah bayi lahir, memberikan air susu ibu ( ASI ) saja atau pemberian Asi secara esklusif sejak lahir sampai bayi berusia 6 bulan, memberikan makanan pendamping Air susu ibu (MPASI) sejak bayi berusia 6-24 bulan serta meneruskan pemberian Asi sampai anak berusia 24 bulan atau lebih. Disamping itu juga MP-ASI disediakan berdasarkan bahan lokal bila memungkinkan MP-ASI harus mudah dicerna, harus disesuaikan dengn umur dan kebutuhan bayi dan MP-ASI harus mengandung kalori dan mikronutrien yang cukup.(Depkes,2010). Pemberian MPASI dini sama saja dengan membuka gerbang bagi masuknya penyakit. Menurut Williams, L dan Wilkin, 2016 hasil riset menunjukkan bahwa bayi yang mendapat 
MP-ASI sebelum berusia 6 bulan lebih sering terkena diare, batuk,pilek, panas, sembelit dibandingkan bayi yang mendapat MP ASI $\geq 6$ bulan. Pudjiadi,2005 dalam Jumiyati menjelaskan bahwa risiko pemberian MP ASI sebelum usia enam bulan adalah kenaikan berat badan yang terlalu cepat (risiko obesitas), alergi terhadap salah satu zat gizi yang terdapat dalam makanan tersebut, mendapat zat-zat tambahan seperti garam dan nitrat yang dapat merugikan. Asupan makanan / minuman selain ASI kepada bayi sebelum usia 6 bulan juga dapat mengakibatkan bayi sering sakit dan memacu timbulnya alergi karena imunitas yang menurun. Akibat akibat tersebut dapat mengganggu pertumbuhan dan perkembangan bayi. ${ }^{3}$

Menurut Lawrence Green (2007) bahwa kesehatan seseorang atau masyarakat dipengaruhi oleh faktor-faktor, yakni faktor perilaku dan faktor diluar perilaku, selanjutnya perilaku itu sendiri ditentukan atau dibentuk dari 3 faktor : faktor predisposisi (predisposing factors)yang terwujud dalam pengetahuan, sikap, kepercayaan, keyakinan, nilai-nilai, dan sebagainya; faktor pendukung (enabling factors) yang terwujud dalam lingkungan fisik, tersedianya atau tidak tersedianya fasilitas-fasilitas atau sarana; faktor pendorong (reinforcing factors) yng terwujud dalam sikap dan perilaku petugas yang merupakan kelompok referensi dari perilaku masyarakat. ${ }^{4}$

Pada penelitian ini ingin diketahui faktor-faktor apakah yang mempengaruhi perilaku pemberian MP-ASI terlalu dini pada bayi $0-6$ bulan di Puskesmas Margadana Kecamatan Margadana Kota Tegal pada tahun 2015. Faktor tersebut adalah faktor usia ibu, pendidikan, pekerjaan, pengetahuan, paritas, faktor budaya dan pengaruh keluarga.

\section{Metode Penelitian}

Penelitian ini bersifat analitik dengan disain cross sectional. Sebagai populasi ditetapkan ibu yang memiliki bayi usia 0-6 bulan yang datang ke Puskesmas pada tahun 2014 sebanyak 163 orang dan diambil sebagai sampel sebanyak 57 orang. Penelitian dilaksanakan pada bulan Mei
Tahun 2015 dan data dikumpulkan dengan cara wawancara kepada responden penelitian meggunakan kuesioner yang telah diuji validitas dan reliabilitasnya. Kemudian dilakukan analisis univariat untuk mengetahui gambaran distribusi frekuensi menurut masing-masing variabel. Uji bivariat juga dilakukan untuk mengetahui hubungan faktor umur, pendidikan, pekerjaan, paritas, faktor budaya dan pengaruh keluarga dengan perilaku pemberian makanan MP-ASI terlalu dini dengan uji Chi Kuadrat dan taraf kesalahan $5 \%$. Hubungan dikatakan signifikan / bermakna bila $\mathrm{p}$-value $<0,05$.

\section{Hasil dan Pembahasan}

Hasil penelitian menunjukkan bahwa dari 57 ibu yang memiliki bayi usia 0-6 bulan di Puskesmas Margadana Kota Tegal, $86 \%$ (49 orang) memberikan MP-ASI secara dini/ kurang dari 6 bulan. Sebagian besar ibu berumur 20-35 tahun $(94,7 \%)$, berpendidikan SD-SMP (63,2\%), tidak bekerja $(64,9 \%)$, primipara $(56,1 \%)$, mendapat pengaruh dari keluarga $(89,5 \%)$ dan dipengaruhi faktor budaya setempat $(70,2 \%)$. Secara rinci gambaran univariat atas faktor-faktor yang diteliti dapat dilihat pada tabel di bawah ini.

Tabel 1. Distribusi frekuensi perilaku pemberian MP-ASI secara dini dan faktor-faktor penyebabnya.

\section{Karakteris tik \\ Jumlah Persen Responden}

\begin{tabular}{lll}
\hline $\begin{array}{l}\text { Perilaku Pemberian } \\
\text { MP-ASI }\end{array}$ & & \\
Baik $(\geq 6$ bulan) & 8 & $14,0 \%$ \\
Kurang (<6 bulan) & 49 & $86,0 \%$ \\
Umur & & \\
$20-35$ tahun & 54 & $94,7 \%$ \\
$>35$ tahun & 3 & $5,3 \%$ \\
Pendidikan & & \\
Rendah (lulus SD) & 36 & $63,2 \%$ \\
Sedang (>lulus SD) & 21 & $36,8 \%$ \\
& & \\
Pekerjaan & & \\
Tidakbekerja & 37 & $64,9 \%$ \\
Bekerja & 20 & $35,1 \%$
\end{tabular}

Pengaruh keluarga 


$\begin{array}{lll}\text { Ya } & 51 & 89,5 \% \\ \begin{array}{l}\text { Tidak } \\ \text { Pengetahuan }\end{array} & 6 & 10,5 \% \\ \text { Ya } & & \\ \text { Tidak } & 39 & 68,4 \% \\ \text { Budaya } & 18 & 31.6 \% \\ \text { Ya } & & \\ \text { Tidak } & 40 & 70,2 \% \\ \text { Paritas } & 17 & 29,8 \% \\ \text { Primipara } & & \\ \text { Multipara } & 32 & 56,1 \% \\ & 25 & 43,9 \%\end{array}$

Adapun setelah dilakukan uji bivariat antara faktor-faktor penyebab dengan perilaku pemberian MP-ASI maka diperoleh hasil sebagai berikut :

Tabel 2. Hubungan Perilaku Pemberian MP-ASI Dini dengan Faktor Penyebabnya.

\begin{tabular}{|c|c|c|c|}
\hline \multirow[t]{2}{*}{ Faktor Risiko } & \multicolumn{2}{|c|}{$\begin{array}{c}\text { Perilaku Pemberian } \\
\text { MP ASI }\end{array}$} & \multirow[t]{2}{*}{$\rho$} \\
\hline & $\begin{array}{l}\text { Baik } \\
n=8\end{array}$ & $\begin{array}{ll}\text { Tidak } & \text { Baik } \\
\text { (Dini) } & \\
n=49 & \end{array}$ & \\
\hline \multicolumn{4}{|l|}{ Umur } \\
\hline $20-35$ th & 7 & 47 & 0,37 \\
\hline$>35$ th & 1 & 2 & \\
\hline \multicolumn{4}{|l|}{ Paritas } \\
\hline Multipara & 4 & 21 & \\
\hline Primipara & 4 & 28 & 0,720 \\
\hline \multicolumn{4}{|l|}{ Pekerjaan } \\
\hline Tidak bekerja & 4 & 33 & \\
\hline Bekerja & 4 & 16 & 0,432 \\
\hline \multicolumn{4}{|l|}{ Pendidikan } \\
\hline Sedang & 5 & 16 & \\
\hline Rendah & 3 & 33 & 0,05 \\
\hline \multicolumn{4}{|l|}{ Pengetahuan } \\
\hline Baik & 5 & 34 & \\
\hline Kurang & 3 & 15 & 0,698 \\
\hline \multicolumn{4}{|l|}{ Pengaruh } \\
\hline \multicolumn{4}{|l|}{ Keluarga } \\
\hline $\mathrm{Ya}$ & 8 & 43 & 0,58 \\
\hline Tidak & 0 & 6 & \\
\hline \multicolumn{4}{|l|}{ Pengaruh } \\
\hline \multicolumn{4}{|l|}{ Budaya } \\
\hline $\mathrm{Ya}$ & 6 & 34 & 1 \\
\hline Tidak & 2 & 15 & \\
\hline
\end{tabular}

Berdasarkan table diatas dapat diketahui bahwa tidak ada hubungan antara umur ibu dengan perilaku pemberian MPASI secara dini yang ditunjukkan dengan nilai $\mathrm{p}<0,05$, yaitu 0,3 . Karakteristik umur mencerminkan kemampuan seseorang dalam berperilaku. Wawan (2010) menyebutkan bahwa semakin banyak umur seseorang maka semakin matang dalam berpikir sehingga semakin bertambahnya umur maka tingkat pengetahuan yang didapatkannya juga pegalaman yang dialami lebih banyak. Pengetahuan akan memudahkan seseorang melakukan sesuatu. ${ }^{4}$ Namun hasil uji statistik menunjukkan tidak ada hubungan antara umur dengan perilaku pemberian MP-ASI sehingga responden dengan usia $<36$ tahun pun banyak yang telah memberikan MPASI dengan baik $\mathrm{Hal}$ ini dapat terjadi dikarenakan semakin berkembang dan menariknya media massa sehingga masyarakat telah terpapar informasi lebih banyak walaupun belum berpegalaman. ${ }^{5}$

Berdasarkan paritas, sebagian besar responden yang berperilaku baik terdapat pada multipara sebanyak 4 responden $(16,0 \%)$ sebaliknya perilaku pemberian MPASI tidak baik terdapat pada primipara sebanyak 28 responden $(87,5 \%)$ tetapi dari hasil uji stasistik didapat nilai $\mathrm{P}$ value $(0,720)>P$ value $(0,05)$ yang berarti tidak terdapat hubungan yang signifikan antara paritas dengan perilaku ibu dalam pemberian makanan pendamping ASI di Puskesmas Margadana Kota Tegal Tahun 2015. Hal ini tidak sesuai dengan teori yang dikemukakan Wawan (2010) bahwa pengalaman merupakan salah satu faktor internal yang mempengaruhi pengetahuan. ${ }^{8}$ Pengetahuan merupakan faktor yang memudahkan seseorang berperilaku. Sehingga semestinya seorang wanita yang memiliki anak lebih banyak maka semakin banyak pula pengetahuan yang dimilikinya. Akan tetapi adanya kemajuan teknologi menyebabkan pengetahuan tidak hanya dapat diperoleh melalui pengalaman tetapi dapat diperoleh melalui paparan media yang bervariasi yang berdampak pada terjadinya perubahan perilaku. Astama (2012) dalam penelitiannya menyebutkan bahwa dengan pemberian pendidikan informasi melalui 
media yang bervariasi membantu meningkatkan pengetahuan masyarakat sehingga masyarakat mau mengubah perilakunya menjadi lebih baik. ${ }^{6}$

Dari tabel 2 di atas juga dapat diketahui bahwa menurut pekerjaan, sebagian besar perilaku baik pada pemberian MP-ASI terdapat pada ibu yang bekerja sebanyak 4 responden $(20,0 \%)$, sebaliknya perilaku pemberian MP-ASI yang tidak baik lebih banyak terdapat pada ibu yang tidak bekerja sebanyak 33 responden $(89,2 \%)$. Tetapi berdasarkan hasil uji analitik didapatkan hasil nilai $\mathrm{P}$ value $(0,432)>$ $(0,05)$, sehingga Ha ditolak dan Ho diterima yang berarti tidak ada hubungan antara perilaku pemberian MP-ASI dengan pekerjaan. Menurut Depkes (2000) bahwa salah satu faktor yang menyebabkan kegagalan ASI eksklusif atau pemberian MP-ASI dini adalah terhentinya pemberian ASI secara dini pada ibu-ibu yang bekerja karena kurangnya pemahaman tentang manajemen laktasi. ${ }^{7}$ Pemberian makanan pendamping dan susu formula untuk jalan alternatif dengan anggapan anak tetap mendapat asupan nutrisi yang cukup merupakan jalan yang ditempuh oleh ibu yang sedang bekerja. Akan tetapi, dengan semakin baiknya sarana prasarana yang menunjang ibu bekerja untuk memberikan ASI ekskluif serta berbagai informasi mengenai manajemen laktasi, baik melalui media maupun kelas ibu hamil dapat memudahkan Ibu bekerja untuk melaksanakan ASI eksklusif atau tidak memberikan MP-ASI secara dini. Sarana prasarana tersebut antara lain tas khusus untuk menyimpan ASI saat bekerja, alat pemerah ASI elektrik, pojok/ruang laktasi di tempat kerja untuk menyusui / memerah ASI, dan lain-lain.

Menurut pendidikan, sebagian besar perilaku pemberian MP-ASI yang baik terdapat pada ibu dengan pendidikan sedang (lulus SMP/SMA) yaitu sebanyak 5 responden $(23,8 \%)$. Sedangkan sebaliknya perilaku pemberian MP-ASI yang tidak baik banyak terdapat pada pendidikan rendah (SD/tidak tamat SD) 33 responden $(91,7 \%)$. Tetapi ternyata setelah dilakukan uji statistik didapatkan hasil nilai $\mathrm{P}$ value lebih besar dari 0,05 , yaitu 0,130 . Ini berarti tidak ada kaitan antara perilaku pemberian MP ASI dengan pendidikan. Responden dengan pendidikan SMP / SMA memiliki perilaku pemberian MP-ASI yang sama dengan responden dengan pendidikan SD/tidak tamat SD . Halini tidak sesuai dengan pendapat Wawan (2010) yang menjelaskan bahwa pendidikan mempengaruhi perilaku. ${ }^{8}$. Pendidikan diperlukan untuk mendapatkan informasi.sehingga pada umumnya semakin tinggi pendidikan seseorang maka semakin mudah menerima informasi dan menyebabkan bertambahnya pengetahuan seseorang. Namun dengan kemajuan teknologi dan bervariasinya media komunikasi maka pengetahuan tidak hanya diperoleh melalui pendidikan. Oleh karena itu pendidikan rendahpun dapat memiliki pengetahuan yang luas bila terpapar informasi media dan akan berdampak pada perilaku.

Menurut pengetahuan, sebagian besar perilaku baik pada pemberian MP-ASI justru terdapat pada ibu dengan pengetahuan kurang 3 responden (16,7\%), sebaliknya perilaku pemberian MP-ASI tidak baik banyak terdapat pada ibu dengan pengetahuan baik sebanyak $34(87,2 \%)$. Ketika dilakukan uji analitik didapatkan hasil nilai $\mathrm{P}$ value 0,698(lebih dari 0,05), sehingga Ha ditolak. Ini berarti tidak ada hubungan antara pengetahuan dengan perilaku pemberian MP-ASI. Sebagaimana disampaikan L.Green bahwa perilaku seseorang tidak hanya dipengaruhi pengetahuan sebagai predisposing faktor, tetapi perilaku juga dipengaruhi oleh faktorfaktor yang lain, yaitu faktor enabling dan faktor reinforcing. ${ }^{4}$ Faktor Enabling adalah sarana dan prasarana yang mendukung seseorang berperilaku sehat, seperti jumlah fasilitas yang ada termasuk jarak dari rumah warga ke fasilitas kesehatan tersebut. Adapun reinforcing faktor adalah faktor pendorong meliputi sikap dan perilaku petugas kesehatan, sikap dan perilaku orang tua, guru dan teman sebaya.

L.Green menyebutkan bahwa pengetahuan merupakan salah satu faktor yang mempengaruhi perilaku. Sedangkan perilaku dipengaruhi oleh faktor internal / dalam diri seseorang dan faktor eksternal. Hal tersebut tidak sejalan dengan hasil 
penelitian ini, dimana dari 57 responden sebagian besar responden, yaitu 51 orang (89,5\%) mengaku mendapatkan pengaruh keluarga dalam pemberian MP-ASI dini dan sebanyak 40 orang $(70,2 \%)$ mengaku mendapatkan pengaruh budaya, dalam hal ini kebiasaan masyarakat di sekitar responden dalam memberikan MP-ASI dini. Akan tetapi ketika dilakukan uji statistic didapatkan hasil $\mathrm{p}$ value $<0,05$. Ini berarti menunjukkan tidak ada hubungan antara pengaruh keluarga terhadap perilaku MPASI.maupun hubungan antara pengaruh budaya terhadap perilaku MP-ASI. Tidak signifikannya hubungan ini kemungkinan disebabkan karena ada faktor-faktor lain yang mempengaruhi perilaku pemberian MP-ASI dini, antara lain faktor persepsi ibu/ responden tentang ketidakcukupan ASI bagi bayinya.

\section{Kesimpulan}

Sebagian besar responden pada penelitian ini berumur 20-35 tahun yaitu 54 responden $(94,7 \%)$, berpendidikan rendah (SD/Tidak sekolah) sebanyak 36 responden $(63,2 \%)$, primipara sebanyak 32 responden $(56,1 \%)$, dan ibu memiliki tingkat pengetahuan baik yaitu sebanyak 39 responden ( 64,8\%). Akan tetapi dari hasil uji Chi kuadrat menunjukkan tidak adanya hubungan antara faktor umur, pendidikan, pekerjaan, pengetahuan, pengaruh keluarga, pengaruh budaya dan paritas terhadap perilaku pemberian MP-ASI dini pada bayi usia 0-6 bulan di Puskesmas Margadana Kota Tegal. Walaupun demikian, masih banyak responden yang mengaku bahwa keluarga dan budaya setempat mempengaruhi perilakunya dalam pemberian MP-ASI dini, sehingga masih perlu dioptimalkan peningkatan pengetahuan keluarga ibu menyusui dan masyarakat tentang pentingnya pemberian MP-ASI dengan tepat. Selain itu perlu diteliti kembali faktor-faktor lain yang diduga mempengaruhi perlaku pemberian MP-ASI yang tidak ada dalam penelitian ini. Faktor tersebut antara lain adalah faktor persepsi ibu terhadap kecukupan ASInya bagi bayi.

\section{Daftar Pustaka}

[1] Depkes RI. Pedoman Umum Pemberian Makanan Pendamping Air Susu Ibu (MPASI) lokal tahun 2006. Jakarta, 2006

[2] Pusat Data dan Informasi Kementrian Kesehatan RI. Infodatin Situasi dan Analisis ASI Eksklusif. Jakarta. 2014

[3] Jumiyati. Pemberian MP-ASI setelah Anak Usia 6 Bulan. Diakses tanggal 25 Juni 2016 di http://180.250.43.170:1782/poltekkes/ files/MPASI.pdf

[4] Notoatmodjo,S.Promosi Kesehatan dan Ilmu Perilaku.Jakarta:Rineka Cipta. 200

[5] Armandhani, H. dan Sukaatmadja, I., 2014. Analisis Perbandingan Brand Equity Produk Obat Anti Nyamuk Oles Merek Autan dengan Merek Soffel di Kota Denpasar. E-Jurnal Manajemen Universitas Udayana, 3(1).

[6] Astama,D. 2012. Pengaruh Pendidikan Kesehatan pada Ibu-ibu Kader Pemberdayaan Keluarga dan Kemasyarakatan (PKK) dalam Mengubah Pengetahuan dan Sikap tentang Pencegahan Demam Berdarah Dengue di Desa Pucangan Kartasura. Naskah Publikasi. Surakarta: Universitas Muhammadiyah Surakarta

[7] Setiawan. Pemberian MP-ASI Dini dan Hubungannya dengan Kejadian Infeksi pada Bayi 0-6 bulan di wilayah Kerja Puskesmas Cipayung, Depok, Skripsi. UI. 2009. Diakses di S-5801-Pemberian-MP-ASILiteratur.pdf-Perpus.lib.ui.ac.id tanggal 25 Juni 2016

[8] Wawan (2010). Teori dan Pengukuran Pengetahuan, Sikap dan Perilaku Manusia. Nuha Medika: Yogyakarta. 